\title{
CIRCADIAN VARIATION IN LOCOMOTORAND FEEDING PERIODS OF TWO LAND SNAIL SPECIES
}

\author{
VARIACIONES CIRCADIANAS EN LOS PERIODOS DE LOCOMOCIÓNY ALIMENTACIÓN \\ DE DOS ESPECIES DE CARACOLES TERRESTRES
}

\author{
Ademolu, K.O.*, Jayeola, O.A., Idowu, A.B. and Elemide, I.O. \\ Biological Sciences Department. University of Agriculture. P.M.B 2240. Abeokuta. Nigeria. \\ *kennyademolu@yahoo.com \\ AdDitionAl KEYWORDS \\ Archachatina marginata. Achatina achatina. \\ PALABRAS CLAVE ADICIONALES \\ Archachatina marginata. Achatina achatina.
}

\section{SUMMARY}

The daily locomotor activities, feeding time and active periods of two snail species (Archachatina marginata and Achatina achatina) were investigated in an artificial habitat. Chemical analysis of the haemolymph were carried out for the 24 hours period. There were differences $(p<0.05)$ in the activities of the 2 snail species. The mean distance traveled by $A$. marginata ranged between $1.9 \mathrm{~cm}$ to $32.6 \mathrm{~cm}$ while $A$. achatina ranged from 1.0 to $18.9 \mathrm{~cm}$. The peak of the feeding activity was at $24.00 \mathrm{~h}$ for both species while the least, was recorded between 4:00 and $20.00 \mathrm{~h}$. The two snail species were most active at 22:0024:00 $\mathrm{h}$ and were least active at 11:00-17:00 h. The chemical analysis of the haemolymph showed difference $(p<0.05)$ in the concentrations of $\mathrm{Cl}^{-}$ and lipids across the 24 hours period.

\section{RESUMEN}

Fueron investigadas la actividades diarias de locomoción, alimentación y periodos activos de dos especies de caracoles Archachatina marginata y Achatina achatina, en un hábitat artificial. Se realizaron análisis químicos de la hemolinfa durante un periodo de 24 horas. Se encontraron diferencias $(p<0,05)$ entre las actividades de las dos especies. La distancia media recorrida por $A$. marginata osciló entre 1,9 y $32,6 \mathrm{~cm}$, mientras que para $A$. achatina fue entre 1,0 y $18,9 \mathrm{~cm}$. El máximo de la actividad alimenticia se registró a las 24:00 horas para ambas especies mientras que la actividad mínima se registró entre las 4:00 y las 20:00

Recibido: 18-2-09. Aceptado: 24-2-10. horas. Las dos especies, estuvieron más activas entre las 22:00 y las 24:00 horas y la actividad fue mínima entre las 11:00 y las 17:00 horas. Hubo diferencias $(p<0,05)$ en la concentración de $\mathrm{Cl}^{-} y$ lípidos de la hemolinfa durante las 24 horas.

\section{INTRODUCTION}

Snails are terrestrial shell bearing animals that belong to Phylum Mollusca and the Class Gastropoda. Land snails are normally more active after dusk and when the ground is damp. Seasonal and diurnal photoperiod have significant regulatory role on invertebrate which they have exploited to adapt to life on land like the vertebrate species (Hodasi, 1982). Snails feed at night and dusk or by day when there is rain or if the sky is overcast, subsisting on both fresh and decomposing plant materials as well as decaying animal materials.

The activities of snails are controlled by exogenous factors (Grimm and Schaumberger, 2002) as well as internal circadian and circanual rhythms. While the nutrition, feeding and circulatory physiology of $A$. marginata and A. achatina have been examined (Ademoluetal., 2006 and Ademolu et al., 2007), little is known about the daily behavior of these snail species. The knowledge of their daily behavioural pattern 
will no doubt be of vital use in the breeding and rearing management. Therefore, the aim of the present study is to establish a complete daily locomotor activity, feeding pattern and active periods for $A$. marginata and $A$. achatina.

\section{MATERIAL AND METHODS}

30 snails (15 each of $A$. marginata and $A$. achatina) of an average weight of 144.55 $\pm 0.1 \mathrm{~g}$ and $126.78 \pm 0.2 \mathrm{~g}$ respectively were purchased from the Snailery of the Forestry and Wildlife Management Department of University of Agriculture, Abeokuta, Nigeria ( $7^{\circ} 15^{\prime} \mathrm{N}$ and $\left.3^{\circ} 25^{\prime} \mathrm{E}\right)$.

Ten snails each of $A$. marginata and $A$. achatina were used for the experiment on daily activities. They were acclimatized for one week after which the experiment was conducted in an artificial habitat made up of

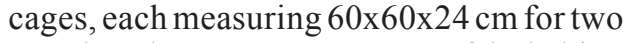
months. The mean temperature of the habitat during the experiment was $26.5 \pm 0.5^{\circ} \mathrm{C}$ while the relative humidity was between $64-70 \%$ (12D:12L).

Duration of different phases in the snails' behaviour was recorded at 60 minute intervals. Locomotor activity was defined as any displacement (distance, measured in $\mathrm{cm}$ using tape rule) of individual snail. Feeding period was determined as the time spent by individual snail at the feeding place. Active time was defined as the time when the snail has released its tentacle from the shell.

The snails were fed with paw-paw leaves (Carica papaya) ad libitum at 6:00 pm daily through out the experiment.

The snails' haemolymph was collected from a different group of ten snails each of A. marginata and A. achatina, by the method described by Ademolu et al. (2006). The haemolymph samples were transferred into bottle with ethylene diamine tetraacetic acid (EDTA, $2 \mathrm{mg} / \mathrm{mL}$ ) as anticoagulant. The collection was done at 6:00; 12:00, 18:00 and 24:00 $\mathrm{h}$ GMT over a period of 24 hours. The protein content was determined by Biuret method (Henry et al., 1974), glucose by colorimetric method (Baummiger, 1974) and lipids by method of Grant (1987). The mineral content $\left(\mathrm{K}^{+}, \mathrm{Na}^{+}, \mathrm{Ca}^{2+}, \mathrm{Cl}^{-}\right.$, and $\left.\mathrm{PO}_{4}{ }^{2-}\right)$ was determined following AOAC (1990).

The data obtained from the haemolymph analysis were analyzed by ANOVA and significant means were separated by Student Newman's-Kuels (SNK).

\section{RESULTS}

The farthest distance covered by $A$. marginata and $A$. achatina were $34.6 \mathrm{~cm}$ and $21.5 \mathrm{~cm}$ respectively and these were in the night (23.00-24.00 h), locomotion started reducing as from 2:00 $\mathrm{h}$ to the zero movement from 10:00-17:00 h. (figure 1). A. marginata traveled significantly more distance than $A$. achatina, nevertheless, it is of interest to note the similarity in the locomotor activity pattern of the two snails species (figure1).

Most feeding occurred during the night from 21:00-2:00 h. However, it could be observed that $A$. marginata spent more time on feeding than $A$. achatina (figure 2).

Major activity of the two snails occurred during the last 6 hours of the day (23:00 in A. marginata and 24:00 in A. achatina. The active time for $A$. marginata ranged between 18:00-10:00 h, while $A$. achatina varies from

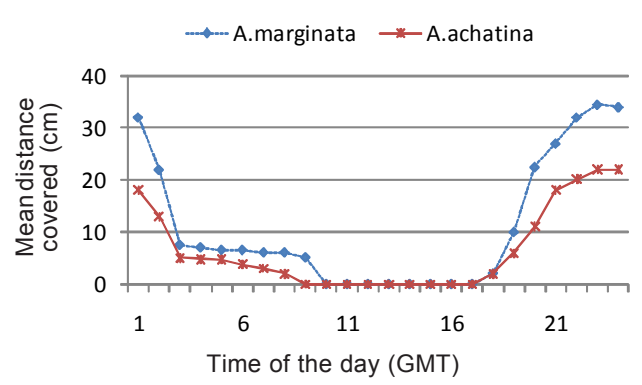

Figure 1. Locomotor activity of Archachatina marginata and Achatina achatina. (Actividad locomotora de Archachatina marginata and Achatina achatina). 


\section{CIRCADIAN VARIATIONS IN LAND SNAILS' ACTIVITIES}

19:00-9:00 h (figure 3).

The lipids content of the haemolymph of A. marginata at 24:00 hour and 6:00 hour were statistically higher $(\mathrm{p}<0.05)$ than the other time of the day while $\mathrm{Cl}^{-}$concentration at 24:00 hour was statistically more than other period of the day except for the 12:00 (table I). The total protein and lipids concentrations of $A$. achatina haemolymph were significantly higher than other period of the day at 6:00 and 24:00 hours respectively. However, the haemolymph $\mathrm{Cl}^{-}$ concentrations at 24:00 and 6:00 hours were not significantlydifferent but were significantly higher than concentrations at 12:00 and 18:00 hours.

\section{DISCUSION}

The results of this study confirm that snails are nocturnal animals. They were very active at night and become inactive during the day time (Akinnusi, 2002 and Hodasi, 1982). The peak level of locomotor activity occurred during the night between the hours of 23.00-24:00 h, while the snails were least active during 10:00-17:00 h. The habit of going out at night was an adaptive mechanism in snails. Snail collectors from the wild thus better aim at them in the night when they are active and out of their shells

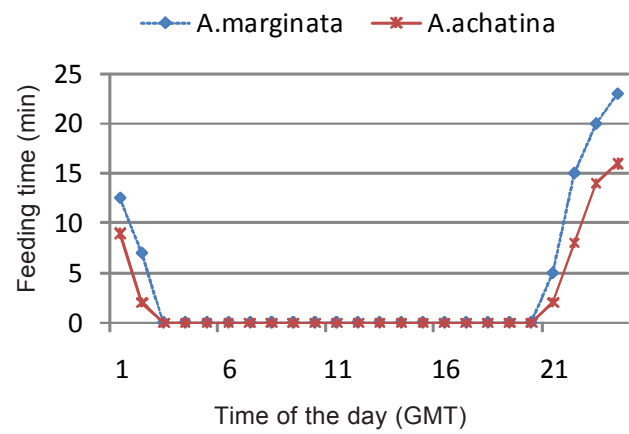

Figure 2. Feeding activities of Archachatina marginata and Achatina achatina. (Actividades alimenticias de Archachatina marginata and Achatina achatina).

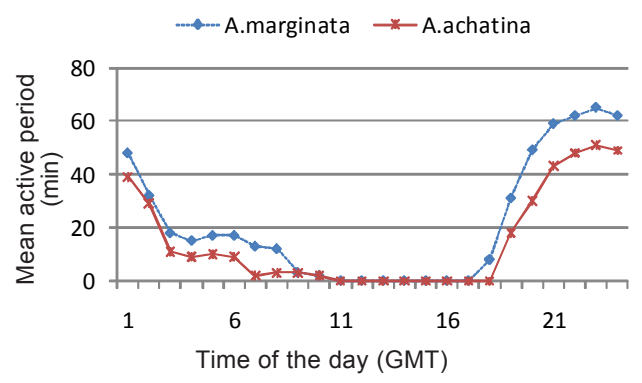

Figure 3. The active period of Archachatina marginata and Achatina achatina. (Periodo activo de Archachatina marginata and Achatina achatina).

The distance traveled by $A$. marginata was significantly $(\mathrm{p}<0.05)$ more than $A$. achatina. This observation agrees with the report of Adeyeye (2001) that A.marginata

Table I. Circadian variation in the haemolymph metabolites of Archachatina marginata and Achatina achatina. (Variación circadiana de los metabolitos de la hemolinfa de Archachatina marginata y Achatina achatina).

\begin{tabular}{lcccc}
\hline & \multicolumn{5}{c}{ Sampling time $(\mathrm{h}),(\mathrm{n}=10)$} \\
& $6: 00$ & $12: 00$ & $18: 00$ & $24: 00$ \\
\hline A. marginata & & & & \\
Glucose $(\mathrm{mg} / \mathrm{dL})$ & 10.3 & 13.3 & 10.0 & 14.0 \\
Total protein $(\mathrm{g} / \mathrm{L})$ & 31.3 & 36.5 & 33.2 & 33.9 \\
Lipids $(\mathrm{mg} / \mathrm{L})$ & $55.1^{\mathrm{a}}$ & $45.7^{\mathrm{c}}$ & $51.4^{\mathrm{b}}$ & $57.1^{\mathrm{a}}$ \\
Calcium mmol/L) & 2.9 & 2.8 & 3.0 & 2.8 \\
Phosphate (mmol/L) & 1.6 & 1.4 & 1.6 & 1.3 \\
Sodium $(\mathrm{mmol} / \mathrm{L})$ & 98 & 106 & 110 & 101 \\
Potassium $(\mathrm{mmol} / \mathrm{L})$ & 3.6 & 4.2 & 3.9 & 3.0 \\
Chloride $(\mathrm{mmol} / \mathrm{L})$ & $42^{\mathrm{b}}$ & $54^{\mathrm{a}}$ & $42^{\mathrm{b}}$ & $55^{\mathrm{a}}$ \\
A. achatina & & & & \\
Glucose $(\mathrm{mg} / \mathrm{dL})$ & 23.3 & 20.5 & 33.5 & 20.0 \\
Total protein $(\mathrm{g} / \mathrm{L})$ & $40.9^{\mathrm{a}}$ & $32.9^{\mathrm{b}}$ & $38.2^{\mathrm{b}}$ & $24.5^{\mathrm{c}}$ \\
Lipids $(\mathrm{mg} / \mathrm{L})$ & $30.4^{\mathrm{b}}$ & $15.4^{\mathrm{c}}$ & $30.9^{\mathrm{b}}$ & $38.5^{\mathrm{a}}$ \\
Calcium mmol/L) & 4.4 & 5.1 & 5.3 & 4.3 \\
Phosphate $(\mathrm{mmol} / \mathrm{L})$ & 1.3 & 3.1 & 1.8 & 0.9 \\
Sodium $(\mathrm{mmol} / \mathrm{L})$ & 132 & 134 & 131 & 136 \\
Potassium $(\mathrm{mmol} / \mathrm{L})$ & 4.9 & 5.6 & 6.8 & 6.8 \\
Chloride $(\mathrm{mmol} / \mathrm{L})$ & $90^{\mathrm{a}}$ & $80^{\mathrm{b}}$ & $82^{\mathrm{b}}$ & $92^{\mathrm{a}}$ \\
\hline
\end{tabular}

abMeans in a row, with different leters, $p<0.05$. 
performed better than A. achatina in terms of movement. This fact should be of importance to snail farmers as it helps in the construction of housing units for these snails' species.

The main feeding period of these two snails' species is in the night. This runs in conformity with the findings of Grimm and Schaumberger (2002) on the slug Arion lusitanicus. Thus, it is advisable to present snails with their feeds late in the evening so as to keep the feed fresh as snails are fond of avoiding obsolete or old foods (Ademolu et al., 2007).

The concentrations of lipids in both snail species were significantly higher at $24: 00 \mathrm{~h}$ (and 6:00 hour for A. achatina) than other periods of the day. The two snails species were at peak of activity between 21:0024:000 h GMT, thus the presence of high concentration of lipids; a high energy

\section{REFERENCES}

Ademolu, K.O., Idowu, A.B. and Agbelusi, O.N. 2006. Effect of stocking density on the growth and haemolymph biochemical value of Archachatina marginata. Trop. Vet., 24: 6-10.

Ademolu, K.O, Idowu, A.B., Mafiana, C.F. and Osinowo O.A. 2007. Performance, proximate, and mineral analysis of African giant snail (Archachatina marginata). Fed different nitrogen sources. Trop. Vet., 25: 124-131.

Adeyeye, E. 2001. Reproduction performance, proximate and mineral composition of three types of land snail found in Nigeria. Int. J. Food Sci. Nutr., 47: 111-116.

Akinnusi, O. 2002. Introduction to snail farming. Triolas Publishing Company. Abeokuta. 70 pp.

AOAC. 1990. Association of official Analytical Chemists. $13^{\text {th }}$ edition. Ed. W. Horwitz. Washington, D.C. $1141 \mathrm{pp}$.

Baummiger, R.N. 1974. Analytical chemistry. source, in the haemolymph at this time make energy readily available for the use of these snails. Olayemi et al. (2006) similarly observed a significantly higher PCV and Total white Blood cell (TWBC) values for African giant rat, (Cricetimys gambianus, Waterhosue) during the day when the rats are most active. Conversely, the least concentrations of lipids were reported at $12: 00 \mathrm{~h}$ and this corresponds to the inactive period of the animal.

It is of significant to note that concentrations of $\mathrm{Na}^{+}, \mathrm{K}^{+}$and $\mathrm{Cl}^{-}$were at the highest value at 24:00 $\mathrm{h}$ in $\mathrm{A}$. achatina (though not statistically different from values at other periods of the day). These ions are involved in the nervous transmission/communication in animal tissues and their high concentration at this time or period suggest a higher activity as they invoke a significant rise in action potential of the excitable tissues.

Cambridge Press. London. pp. 83-85.

Grimm, B. and Schaumberger, K. 2002. Daily activity of the pest slug Arion insitanicus under laboratory condition. Ann. Appl. Biol., 141: 35-44.

Grant, G.H. 1987. Amino acids and protein: Fundamentals of clinical chemistry. WB Sander Company. Philadelphia. U.S.A. pp. 326-329.

Henry, R.J., Canon, D.C. and Winkalman, J.W. 1974. Clinical chemistry: Principle and technique $2^{\text {nd }}$ ed. Harper and Row Publishers. New York. pp. 54-56.

Hodasi, J.K.N. 1982. The effect of different light regimes on the behavior and biology of Achatina achatina. J. Mollus. Stud., 48: 1-7.

Olayemi, F.O., Sanni, A.A., Awonuga, M.A., Oke, O.A. and Ogunsanmi, O.A. 2006. Diurnal variation in the haematological values of the African giant rat (Cricetomys gambianus, Waterhouse). Trop. Vet., 24: 11-15. 